\title{
The land flatworm Amaga expatria (Geoplanidae) in Guadeloupe and Martinique: new reports and molecular characterization including complete mitogenome
}

\author{
Jean-Lou Justine ${ }^{\text {Corresp., }}{ }^{,}$, Delphine Gey ${ }^{2}$, Jessica Thévenot ${ }^{3}$, Romain Gastineau ${ }^{4}$, Hugh D Jones ${ }^{5}$ \\ ${ }^{1}$ ISYEB - Institut de Systématique, Évolution, Biodiversité, Muséum National d'Histoire Naturelle, Paris, France \\ 2 Molécules de Communication et Adaptation des Micro-Organismes, Museum national d'Histoire naturelle, Paris, France \\ 3 Patrinat, Museum national d'Histoire naturelle, Paris, France \\ 4 Institute of Marine and Environmental Sciences, University of Szczecin, Szczecin, Poland \\ 5 Life Sciences Department, Natural History Museum, London, United Kingdom \\ Corresponding Author: Jean-Lou Justine \\ Email address: justine@mnhn.fr
}

Background. The land flatworm Amaga expatria Jones \& Sterrer, 2005 (Geoplanidae) was described from two specimens collected in Bermuda in 1963 and 1988 and not recorded since. Methods. On the basis of a citizen science project, we received observations in the field, photographs and specimens from non-professionals and local scientists in Martinique and Guadeloupe. We barcoded (COI) specimens from both islands and studied the histology of the reproductive organs of one specimen. Based on Next Generation Sequencing, we obtained the complete mitogenome of $A$. expatria and some information on its prey from contaminating DNA. Results. We add records from 2006 to 2019 in two French islands of the Caribbean arc, Guadeloupe (six records) and Martinique (14 records), based on photographs obtained from citizen science and specimens examined. A specimen from Martinique was studied for histology of the copulatory organs and barcoded for the COI gene; its anatomy was similar to the holotype, therefore confirming species identification. The COI gene was identical for several specimens from Martinique and Guadeloupe and differed from the closest species by more than 10\%; molecular characterisation of the species is thus possible by standard molecular barcoding techniques. The mitogenome is 14962 bp in length and contains 12 protein coding genes, two rRNA genes and 22 tRNA genes; for two protein genes it was not possible to determine the start codon. The mitogenome was compared with the few available mitogenomes from geoplanids and the most similar was Obama nungara, a species from South America. An analysis of contaminating DNA in the digestive system suggests that $A$. expatria preys on terrestrial molluscs, and citizen science observations in the field suggest that prey include molluscs and earthworms; the species thus could be a threat to biodiversity of soil animals 
in the Caribbean. 
1 The land flatworm Amaga expatria (Geoplanidae) in Guadeloupe and

2 Martinique: new reports and molecular characterization including complete

3 mitogenome

4

5 Jean-Lou Justine ${ }^{1 *}$, Delphine Gey ${ }^{2}$, Jessica Thévenot ${ }^{3}$, Romain Gastineau ${ }^{4}$ and

6 Hugh D. Jones 5

7

$8 \quad{ }^{1}$ ISYEB - Institut de Systématique, Évolution, Biodiversité, Muséum National d'Histoire

9 Naturelle, Paris, France

$10 \quad{ }^{2}$ Molécules de Communication et Adaptation des Micro-Organismes, Museum national

11 d'Histoire naturelle, Paris, France

$12{ }^{3}$ Patrinat, Museum national d'Histoire naturelle, Paris, France

$13{ }^{4}$ Institute of Marine and Environmental Sciences, University of Szczecin, PL-70-383 Szczecin,

14 Poland

$15 \quad{ }^{5}$ Scientific Associate, Life Sciences Department, Natural History Museum, London, SW7 5BD, UK.

$16 *$ Corresponding author: justine@mnhn.fr

17

18

19 


\section{Abstract}

22 Background. The land flatworm Amaga expatria Jones \& Sterrer, 2005 (Geoplanidae) was

23 described from two specimens collected in Bermuda in 1963 and 1988 and not recorded since.

24 Methods. On the basis of a citizen science project, we received observations in the field, 25 photographs and specimens from non-professionals and local scientists in Martinique and 26 Guadeloupe. We barcoded (COI) specimens from both islands and studied the histology of the 27 reproductive organs of one specimen. Based on Next Generation Sequencing, we obtained the 28 complete mitogenome of $A$. expatria and some information on its prey from contaminating DNA.

30 Results. We add records from 2006 to 2019 in two French islands of the Caribbean arc,

31 Guadeloupe (six records) and Martinique (14 records), based on photographs obtained from

32 citizen science and specimens examined. A specimen from Martinique was studied for histology

33 of the copulatory organs and barcoded for the COI gene; its anatomy was similar to the holotype, 34 therefore confirming species identification. The COI gene was identical for several specimens 35 from Martinique and Guadeloupe and differed from the closest species by more than 10\%; 36 molecular characterisation of the species is thus possible by standard molecular barcoding 37 techniques. The mitogenome is $14962 \mathrm{bp}$ in length and contains 12 protein coding genes, two 38 rRNA genes and 22 tRNA genes; for two protein genes it was not possible to determine the start codon. The mitogenome was compared with the few available mitogenomes from geoplanids and

40 the most similar was Obama nungara, a species from South America. An analysis of

41 contaminating DNA in the digestive system suggests that $A$. expatria preys on terrestrial

42 molluscs, and citizen science observations in the field suggest that prey include molluscs and 43 earthworms; the species thus could be a threat to biodiversity of soil animals in the Caribbean. 


\section{Introduction}

46 The land flatworm Amaga expatria Jones \& Sterrer, 2005 (Platyhelminthes, Geoplanidae) was

47 described from two specimens collected in Bermuda in 1963 and 1988 (Jones \& Sterrer 2005). It

48 has not been recorded since. Jones \& Sterrer (2005) concluded that the species was an alien 49 species in Bermuda, probably introduced from South America since other members of the genus

50 have been collected in this region, including Colombia, Peru, Chile, Brazil, Paraguay and 51 Argentina (Ogren \& Kawakatsu 1990); the genus Amaga Ogren \& Kawakatsu, 1990 currently 52 includes 10 species (Grau et al. 2012).

In 2003, one of us (JLJ) undertook a citizen science program in France about alien land flatworms. Records were unexpectedly received from other locations including French overseas territories (Justine et al. 2014, 2015, 2018a, 2018b, 2019; Justine \& Winsor 2020). Among these were several records of large land flatworms from the two Caribbean islands of Martinique and Guadeloupe with similar dimensions and pigmentation to $A$. expatria and tentatively identified as such. To confirm this identification, one specimen from Martinique has been partially sectioned for anatomical comparison with the type material. The same specimen was also subjected to molecular sequencing (COI barcoding). Another specimen from Martinique was included in a comparative study of the mitogenome of several land flatworms (Gastineau \& Justine 2020; Gastineau et al. 2019, 2020).

We present here new records of $A$. expatria in two islands of the Caribbean, and provide additional morphological information, the first barcoding characterisation of the species and its complete mitogenome.

\section{Material and Methods}

\section{Citizen science and collection of information}

Records were collected from 2013 to 2019, a period of 7 years (single records from 2006 and 2012 are also included). We used the same methods as for our previous research on land flatworms (Justine et al. 2014, 2015, 2018a, 2018b, 2019). A blog (Justine 2019) and a twitter account (@Plathelminthe4)were the main tools for collecting and transmitting information. The collaboration of local natural history associations and of the FREDON (Regional federations for 
73 the control of pests) in the departments of Martinique and Guadeloupe was also instrumental.

74 Reports of sightings were received from the general public and from professionals, generally by

75 email. We solicited and obtained specimens. Specimens were obtained alive, fixed in near

76 boiling water and preserved in $95 \%$ ethanol, or sometimes fixed directly in cold ethanol. They

77 were sent to the Muséum National d'Histoire Naturelle (MNHN) in Paris, registered, and

78 processed for molecular studies.

\section{Histology}

80 A specimen from Martinique, MNHN JL146, was used for histology. It was killed alive in

81 boiling water, then kept in $80 \%$ ethanol. A portion about $1.7 \mathrm{~cm}$ long containing the copulatory

82 apparatus was removed for sectioning. Horizontal longitudinal sections (HLS) were cut at $12 \mu \mathrm{m}$

83 thickness, mounted on 41 slides, stained in haematoxylin and eosin and mounted in Canada

84 balsam (slides 1-5 and 38-41 remain unstained in wax). Slides are deposited in the MNHN, Paris,

85 registration number MNHN JL146.

86

87

88

89

90

91

92

93

94

\section{Molecular barcoding}

For molecular analysis, a small piece of the body $\left(1-3 \mathrm{~mm}^{3}\right)$ was taken from the lateral edge of ethanol-fixed individuals. Extraction of DNA and PCR were performed as in previous similar works (Justine et al. 2019). Briefly, a fragment of 424 bp was amplified with the primers JB3 (=COI-ASmit1) and JB4.5 (=COI-ASmit2) (Bowles et al. 1995; Littlewood et al. 1997), and a fragment of $825 \mathrm{bp}$ was amplified with the primers BarS (Álvarez-Presas et al. 2011) and COIR (Lázaro et al. 2009; Mateos et al. 2013). PCR products were purified and sequenced in both directions on a 96-capillary 3730xl DNA Analyzer sequencer (Applied Biosystems). Results of both analyses were concatenated to obtain a COI sequence of $903 \mathrm{bp}$ in length. Sequences were edited using CodonCode Aligner software (CodonCode Corporation, Dedham, MA, USA), compared to the GenBank database content using BLAST, and deposited in GenBank under accession number MT602619-MT602626..

\section{Next Generation Sequencing, phylogeny and identification of contaminant DNA}

A slice of flesh from specimen MNHN JL305 was sent to the Beijing Genomics Institute (BGI) in Shenzhen, which provided DNA extraction and sequencing. Sequencing was performed on a DNBSEQ platform. A total of ca. 60 million clean paired-end reads were obtained. Reads were 
102 assembled using SPAdes 3.14.0 (Bankevich et al. 2012) with a k-mer of 85. Contigs

103 corresponding to the mitogenome and the nuclear ribosomal RNA genes were retrieved by

104 customized blastn command line analyses, using already available sequences downloaded from

105 GenBank as a custom database; ribosomal RNA genes (not used in this paper), were deposited

106 into GenBank as MT860713 (18S) and MT860719 (partial 28S). In addition to the sequences

107 related to A. expatria, other positive matches belonging to contaminant DNA were obtained as

108 explained in the results. tRNA were identified using tRNA-scan (Lowe \& Chan 2016). The

109 mitogenome was verified using the Consed package (Gordon et al. 1998), and gene identification

110 was performed using MITOS (Bernt et al. 2013). The genomic map was drawn using OGDRAW

111 (Lohse et al. 2013). Amino acid sequences of the protein coding genes were concatenated

112 following a protocol already described (Gastineau \& Justine 2020; Gastineau et al. 2019;

113 Gastineau et al. 2020), and aligned with corresponding sequences from other species using

114 MAFFT (Katoh \& Standley 2013); we used the command-line version of MAFFT, with the

115 option "G-INS-I". A maximum likelihood phylogeny was inferred from this alignment using

116 RaxML version 8.0 (Stamatakis 2014) using the MtArt substitution model (Abascal et al. 2007).

117 The best tree out of 100 was computed for 100 bootstrap replicates.

118 COI trees and distances

119 MEGA7 (Kumar et al. 2016) was used to evaluate distances, and construct trees. For the

120 outgroup, we chose a sequence in GenBank from the South American species O. nungara

121 Carbayo, Álvarez-Presas, Jones \& Riutort, 2016 (Carbayo et al. 2016) (MN529572) which had a

$122100 \%$ query cover with our sequences.

\section{Results}

\section{Information obtained from citizen science and other scientists}

125 We obtained 14 verified records from Martinique (map in Figure 1), from 2006 to 2018, and six

126 verified records from Guadeloupe, from 2012 to 2018 (map in Figure 2). Records were generally

127 obtained as photographs, but we also received five specimens from Martinique and three

128 specimens from Guadeloupe (Table 1). In addition, François Meurgey (email, 29.01.2016) added

129 information about Guadeloupe: "Amaga expatria is quite common in the high series of the

130 mesophilic forest and between 400 and $700 \mathrm{~m}$ altitude in the moist forest. I met it in the 
131 municipalities of Baillif (St Louis river), Matouba, Trois-Rivières, and Gourbeyre. It seems more

132 frequent in the South of Basse-Terre. I have observed it attacking snails of the genera Helicina,

133 Pleurodonte and earthworms.” Laurent Charles (email, 15.05.2020) sent a photograph showing

134 predation on a snail identified as Helicina platychila (Megerle von Mühlfeld, 1824).

\section{Morphology and histology}

136 Live specimens mentioned in this study, measured on photographs (Figures 3-5), were 128-132

$137 \mathrm{~mm}$ in length and 5.5-9 $\mathrm{mm}$ in width in extended state, and $35 \times 12 \mathrm{~mm}$ in contracted state.

138 Description of Specimen MNHN JL146.

139 Living dimensions (Figure 3): length $128 \mathrm{~mm}$, width $5.5 \mathrm{~mm}$. Preserved dimensions: length 108 $140 \mathrm{~mm}$, width $9 \mathrm{~mm}$, height $2 \mathrm{~mm}$; mouth 53\%; genital pore $75 \%$.

141 The copulatory apparatus (Figure 6) is about $8 \mathrm{~mm}$ long from the anterior of the male system to

142 the posterior of the female system. The male system is about $5 \mathrm{~mm}$ long and the female system

143 about $3 \mathrm{~mm}$ long.

144 Two sperm ducts, about $1.2 \mathrm{~mm}$ apart, each with copious stored sperm (cyanophylic) approach

145 the copulatory apparatus, briefly turn anteriorly before opening separately into the ventral end of

146 a single duct (Figure 6d). This duct has a thick muscular wall and runs vertically from ventral to

147 dorsal for about $1080 \mu \mathrm{m}$ (runs through 90 sections x $12 \mu \mathrm{m}$ ). At its dorsal end this duct

148 continues posteriorly as a narrow sinuous duct before broadening into the ejaculatory duct. The

149 ejaculatory duct terminates in a short penis about $800 \mu \mathrm{m}$ long and $600 \mu \mathrm{m}$ wide (Figure 6a,b).

150 There are atrial folds outside the penis in the common antrum.

151 The two ovovitelline ducts (Figure 6a,b) are about $2 \mathrm{~mm}$ apart anterior to the penis, they run

152 posteriorly and at about the level of the penis they turn dorsally to join and open into the

153 combined female duct. Copious shell glands (eosinophilic) are present and open into both

154 ovovitelline ducts before they join (Figure $6 \mathrm{c}$ ) to form the combined female duct. The combined

155 female duct broadens, and has one or two longitudinal folds, before opening into the common 156 antrum.

157 The gonopore opens from the common antrum via a short, narrow duct. 
158 Molecular characterization - COI

159 For 4 specimens, the amplified COI sequences obtained were identical along their whole length 160 (903 bp). These specimens were JL289, JL305 (obtained both from Sanger sequencing and from 161 the mitogenome) and JL310 from Martinique, and JL319 from Guadeloupe. This demonstrates

162 that the same species was found in both islands. Specimen JL146 from Martinique, which was

163 processed for histology, and three other specimens, JL216 and JL217 from Guadeloupe and

164 JL262 from Martinique, provided shorter sequences but these were also identical between them

165 and with the 4 sequences above for their portion in common. This demonstrates that the

166 specimen studied for histology is from the same species, therefore confirming that the species in 167 both islands is $A$. expatria. Differences with $O$. nungara, calculated on the $903 \mathrm{bp}$ in common, 168 were $12 \%$.

\section{Mitogenome}

170 The mitogenome (Figure 7) is 14962 bp long (GenBank accession number: MT527191). It

171 contains 12 protein coding genes, 2 ribosomal RNA genes and 22 transfer RNA genes. The

172 mitogenome is completely colinear with that of O. nungara (KP208777) (Solà et al. 2015) and

173 similar in size (14909 bp for O. nungara). A megablast query using the whole sequence of the

174 mitogenome shows a global $83.77 \%$ identity between these two species. The mitogenome is also

175 colinear with those of Bipalium kewense, but not with those of Platydemus manokwari and

176 Parakontikia ventrolineata. For 3 genes, atp6, cox2 and ND3, it was not possible to determine

177 the start codon. The first methionine of the predicted proteins occurs at position 72/224 for atp6,

$178112 / 260$ for $\operatorname{cox} 2$ and 44/112 for ND3. It is worth mentioning that the impossibility to evidence a

179 start codon for these genes was observed with O. nungara, but not for example with B. kewense,

$180 \mathrm{Pl}$. manokwari or Pa. ventrolineata. Unlike $O$. nungara, however, no overlap between the ND4L

181 and ND4 genes was evidenced.

182 In the tree representing a maximum likelihood phylogeny of amino acid sequences of protein

183 coding genes, A. expatria is the sister-group of O. nungara (Figure 8).

\section{Detection of an alien DNA}

185 After assembly, sequences linked with contaminating DNA were identified. Three contigs of

1863080 bp, 7274 bp and 15202 bp were retrieved. Megablast analyses were performed on the NCBI 
187 portal. The best results are listed thereafter. The $3080 \mathrm{bp}$ fragment displayed a $99.66 \%$ of identity

188 with the $18 \mathrm{~S}$ ribosomal genes of sequences identified as the molluscs Subulina striatella (Rang,

189 1831) (MN022690), Lissachatina fulica (MN022692) and Achatina fulica (Férussac, 1821)

190 (KU365375). The 7274 bp fragment showed a 99.97\% of identity with the internal transcribed

191 spacer 2 of a sequence identified as Subulina octona (Bruguière, 1789) (MF444887). The longest

192 fragment appeared to be a nearly complete mitochondrial genome. The cox 1 gene was extracted

193 from it, and it showed a $97.86 \%$ of identity with S. octona (JX988065).

\section{Discussion}

\section{New records}

196 Amaga expatria was described on the basis of two specimens from Bermuda, the holotype,

197 collected in 1988, and a paratype, collected in 1963 (Jones \& Sterrer 2005). The species has not

198 been recorded since, but was mentioned in a book on molluscs of Martinique (Delannoye et al.

199 2015). These were originally identified by one of us (JLJ) and are also included in the present

200 study. Our study has ten times more records than the original description, with 6 records from

201 Guadeloupe and 14 records from Martinique (Table 1). This exemplifies again the power of

202 citizen science for recording land flatworms (Justine et al. 2018b, 2019).

203 Maps (Figures 1-2) show that the species is widely spread in both Martinique and Guadeloupe.

204 In Guadeloupe, most records were from Basse Terre and a single record (Sainte-Anne) was from

205 Grande Terre, and in Martinique, most records were from the North of the island, with only one

206 in the South, in Sainte-Luce. This suggests that the species is more abundant in, but not exclusive

207 to, the parts of the islands with higher rainfalls (Basse Terre in Guadeloupe and the North in

208 Martinique).

\section{Anatomy and morphology}

210 The copulatory apparatus of the Martinique specimen (Figure 6) is essentially the same as the

211 type specimen of $A$. expatria from Bermuda (NHMUK.2002.10.16.1). The afferent male ducts

212 have a similar structure, with two sperm ducts discharging into a ventro-dorsal duct which in turn

213 opens into the ejaculatory duct and blunt penis via a sinuous duct. The duct wall is thickened in

214 the same position about half way between the vertical duct and penis. We are confident of the

215 identification of the Martinique specimen (MNHN JL146) as A. expatria. Given this and the 
216 similarity of the external characteristics of the specimens from Martinique, Guadeloupe and

217 Bermuda, we are confident that all specimens are $A$. expatria.

\section{Diet}

219 Analysis of prey DNA is an efficient method to determine the diet of land planarians (Cuevas-

220 Caballé et al. 2019). All BLAST analyses of the contaminant DNA in a specimen of $A$. expatria

221 identified it as belonging to the Gastropoda, and it is likely that the prey was a specimen of

222 Subulina octona, or a closely related species. Subulina octona is a tropical terrestrial snail, with a

223 cosmopolitan distribution; this mollusc is indeed present in Martinique where it is considered

224 recently introduced (Anonymous 2020).

225 The original description of $A$. expatria included no direct observation about the diet, but Jones \&

226 Sterrer (2005), on the basis of the presence of a plicate pharynx, wrote "it is likely that

227 earthworms are the sole or principal prey of $A$. expatria". The observations by François Meurgey

228 (predation on snails of the genera Helicina, Pleurodonte and earthworms) and Laurent Charles

229 (predation on Helicina platychila) reported here, and the finding of the sequence of a terrestrial

230 mollusc in the gut, indicate a generalist diet, including both molluscs and earthworms. This diet

231 might be one of the reasons of the success of the species to invade various islands in the

232 Caribbean.

\section{Molecular barcoding}

234 One specimen from Martinique was characterised for morphology, histology, and barcoding and

235 thus represents the first attempt at a molecular characterization of the species. Specimens from

236 Martinique and Guadeloupe provided identical sequences, therefore unequivocally

237 demonstrating that the same species is present on both islands, and, from morphology and

238 anatomy, is $A$. expatria. The absence of genetic divergence between our sequenced specimens

239 suggests that the species was recently introduced into the two islands from a single population.

240 The COI sequence closest to A. expatria found by BLAST was $O$. nungara, with a significant

241 difference of $12 \%$. This suggests that the COI sequences can be used for barcoding A. expatria,

242 but this should be validated in the future by a comparative study with sequences of other species

243 of Amaga, which are currently not available. 


\section{Mitochondrial genome and multigene phylogeny}

245 In the maximum likelihood multigene phylogeny, the clade including A. expatria and O. nungara

246 has a strong node support of 100 , which is congruent with their position in the same Geoplaninae

247 sub-family (Figure 8). It clearly discriminates them from the Bipaliinae B. kewense, the

248 Caenoplaninae Pa. ventrolineata and the Rhynchodeminae Pl. manokwari.

249 Among the features conserved between the mitogenomes of A. expatria and $O$. nungara, we 250 would like to emphasize the conserved absence of canonical start codons for the three genes 251 atp6, cox2 and ND3. Instead, the first amino-acids evidenced from the putative proteins are 252 always a leucine. This leucine is always coded by a TTG codon, except for $A$. expatria where it 253 is replaced by TTA. While no such thing has been evidenced among the recently sequenced 254 mitogenomes of B. kewense, Pl. manokwari and Pa. ventrolineata (Gastineau \& Justine 2020;

255 Gastineau et al. 2019, 2020), similar features have also been observed among several Dugesiidae 256 such as Dugesia japonica AB618487, Dugesia ryukyuensis AB618488 (both in Sakai \&

257 Sakaizumi 2012), Girardia sp. KP090061 and Schmidtea mediterranea NC_022448 and

258 KM821047 (both in Ross et al. 2016). The possibility that TTG could act as an alternative start 259 codon was already suggested by Ross et al. (2016). Based on our data, we may suggest that TTA 260 could also be considered. Addressing properly this question might require $\mathrm{N}$-terminal sequencing 261 of these proteins.

262 We note that Amaga and Obama belong to the subfamily Geoplaninae, whereas Platydemus and 263 Parakontikia are members of the Rhynchodeminae and Bipalium is a member of the Bipaliinae.

264 This possible variation of the genetic code could thus be limited to a single subfamily within the 265 Geoplanidae, the Geoplaninae.

\section{Conclusion}

267 Our study shows that a relatively large land flatworm species is common in two islands of the 268 Caribbean, and, with 20 new records, adds ten times the previous number of records of the 269 species, which were from a single location, Bermuda, an island located in the Northeast Atlantic 270 Ocean. Jones \& Sterrer (2005) hypothesized that the species originated from continental South

271 America and was recently introduced in the Bermuda. Our genetic results show that COI

272 sequences from Martinique and Guadeloupe were identical and thus suggest that the introduction 
273 is recent in these islands. It remains that the locality of origin of the species in South America is

274 still unknown. The species preys on molluscs and earthworms and might be a threat to the

275 biodiversity of soil animals, especially molluscs which include endemic and rare species in the

276 Caribbean islands (Delannoye et al. 2015). However, no proliferation was recorded and the threat

277 may be minor, but it might also be that A. expatria is only in the first stages of invasion and that

278 it will become an invading species in the future; similarly, recent observations have shown that

279 the highly invasive species Platydemus manokwari is now invading Guadeloupe (Justine \&

280 Winsor 2020). The presence of A. expatria in two islands of the Caribbean suggests that it might

281 be present in other islands, and perhaps in continental North America.

\section{Acknowledgments}

283 We are grateful to all non-professionals and professionals who provided records and specimens;

284 they are listed in Table 1. All individuals listed in Table 1 kindly agreed to have their

285 photographs published in this paper. François Meurgey and Laurent Charles kindly

286 communicated some field observations; Laurent Charles provided information about the status of

287 Subulina octona; they both agreed to have their information communicated here. Leigh Winsor

288 (James Cook University, Australia) kindly helped in identifying specimens on photograph at

289 early stages of this work. 


\section{References}

291 Abascal F, Posada D, and Zardoya R. 2007. MtArt: a new model of amino acid replacement for Arthropoda. Molecular Biology and Evolution 24:1-5.

293

294

295

296

297

298

299

300

301

302

303

304

305

306

307

308

309

310

311

312

313

314

315

Álvarez-Presas M, Carbayo F, Rozas J, and Riutort M. 2011. Land planarians (Platyhelminthes) as a model organism for fine-scale phylogeographic studies: understanding patterns of biodiversity in the Brazilian Atlantic Forest hotspot. Journal of Evolutionary Biology 24:887-896.

Anonymous. 2020. La Liste rouge des espèces menacées en France. Faune de Martinique. Comité français de l'UICN, OFB \& MNHN. available from: https://inpnmnhnfr/docs/LR_FCE/Fascicule_liste_rouge_faune_martinique_2020_04_vfp df (consulted 14 May 2020).

Bankevich A, Nurk S, Antipov D, Gurevich AA, Dvorkin M, Kulikov AS, Lesin VM, Nikolenko SI, Pham S, and Prjibelski AD. 2012. SPAdes: a new genome assembly algorithm and its applications to single-cell sequencing. Journal of Computational Biology 19:455-477.

Bernt M, Donath A, Jühling F, Externbrink F, Florentz C, Fritzsch G, Pütz J, Middendorf M, and Stadler PF. 2013. MITOS: improved de novo metazoan mitochondrial genome annotation. Molecular Phylogenetics and Evolution 69:313-319.

Bowles J, Blair D, and McManus DP. 1995. A molecular phylogeny of the human schistosomes. Molecular Phylogenetics and Evolution 4:103-109.

Carbayo F, Álvarez-Presas M, Jones HD, and Riutort M. 2016. The true identity of Obama (Platyhelminthes: Geoplanidae) flatworm spreading across Europe. Zoological Journal of the Linnean Society 177:5-28.

Cuevas-Caballé C, Riutort M, and Álvarez-Presas M. 2019. Diet assessment of two land planarian species using high-throughput sequencing data. Scientific Reports 9:8679.

Delannoye R, Charles L, Pointier J-P, and Massemin D. 2015. Mollusques continentaux de la Martinique: Muséum national d'Histoire naturelle. 
316 Gastineau R, and Justine J-L. 2020. Complete mitogenome of the invasive land flatworm

317

318

319

320

321

322

323

324

325

326

327

328

329

330

331

332

333

334

335

336

337

338

339

Parakontikia ventrolineata, the second Geoplanidae (Platyhelminthes) to display an unusually long cox2 gene. Mitochondrial DNA Part B 5:2115-2116.

Gastineau R, Justine J-L, Lemieux C, Turmel M, and Witkowski A. 2019. Complete mitogenome of the giant invasive hammerhead flatworm Bipalium kewense. Mitochondrial DNA Part B 4:1343-1344.

Gastineau R, Lemieux C, Turmel M, and Justine J-L. 2020. Complete mitogenome of the invasive land flatworm Platydemus manokwari. Mitochondrial DNA Part B 5:1689-1690.

Gordon D, Abajian C, and Green P. 1998. Consed: a graphical tool for sequence finishing. Genome research 8:195-202.

Grau JH, Sluys R, Froehlich EM, and Carbayo F. 2012. Reflections on the genus Amaga Ogren and Kawakatsu 1990, and description of a new genus of land planarian (Platyhelminthes: Tricladida: Geoplanidae). Journal of Natural History 46:1529-1546.

Jones HD, and Sterrer W. 2005. Terrestrial planarians (Platyhelminthes, with three new species) and nemertines of Bermuda. Zootaxa 1001:31-58.

Justine J-L. 2019. Plathelminthes terrestres invasifs. Blog (in French). https://sites.google.com/site/jljjustine/plathelminthe-terrestre-invasif.

Justine J-L, Lemarcis T, Gerlach J, and Winsor L. 2018a. First report of the land planarian Endeavouria septemlineata (Hyman, 1939) (Platyhelminthes, Tricladida, Continenticola, Geoplanidae) in French Polynesia. Zootaxa 4450:297-300.

Justine J-L, Winsor L, Barrière P, Fanai C, Gey D, Han AWK, La Quay-Velazquez G, Lee BPYH, Lefevre J-M, Meyer J-Y, Philippart D, Robinson DG, Thévenot J, and Tsatsia F. 2015. The invasive land planarian Platydemus manokwari (Platyhelminthes, Geoplanidae): records from six new localities, including the first in the USA. PeerJ 3:e1037. 
340 Justine J-L, Winsor L, Gey D, Gros P, and Thévenot J. 2014. The invasive New Guinea flatworm

341

342

343

344

345

346

347

348

349

350

351

352

353

354

355

356

357

358

359

360

361

362

363

364

365

366 Platydemus manokwari in France, the first record for Europe: time for action is now. PeerJ 2:e297.

Justine J-L, Winsor L, Gey D, Gros P, and Thévenot J. 2018b. Giant worms chez moi! Hammerhead flatworms (Platyhelminthes, Geoplanidae, Bipalium spp., Diversibipalium spp.) in metropolitan France and overseas French territories. PeerJ 6:e4672.

Justine J-L, Winsor L, Gey D, Gros P, and Thévenot J. 2019. Obama chez moi! The invasion of metropolitan France by the land planarian Obama nungara (Platyhelminthes, Geoplanidae). PeerJ 8:e8385.

Justine JL, and Winsor L. 2020. First record of presence of the invasive land flatworm Platydemus manokwari (Platyhelminthes, Geoplanidae) in Guadeloupe. Preprints 2020:2020050023.

Katoh K, and Standley DM. 2013. MAFFT multiple sequence alignment software version 7: improvements in performance and usability. Molecular Biology and Evolution 30:772780.

Kumar S, Stecher G, and Tamura K. 2016. MEGA7: Molecular Evolutionary Genetics Analysis version 7.0 for bigger datasets. Molecular Biology and Evolution 33:1870-1874.

Lázaro EM, Sluys R, Pala M, Stocchino GA, Baguñà J, and Riutort M. 2009. Molecular barcoding and phylogeography of sexual and asexual freshwater planarians of the genus Dugesia in the Western Mediterranean (Platyhelminthes, Tricladida, Dugesiidae). Molecular Phylogenetics and Evolution 52:835-845.

Littlewood DTJ, Rohde K, and Clough KA. 1997. Parasite speciation within or between host species? - Phylogenetic evidence from site-specific polystome monogeneans. International Journal for Parasitology 27:1289-1297.

Lohse M, Drechsel O, Kahlau S, and Bock R. 2013. OrganellarGenomeDRAW—a suite of tools for generating physical maps of plastid and mitochondrial genomes and visualizing expression data sets. Nucleic Acids Research 41:W575-W581. 
367 Lowe TM, and Chan PP. 2016. tRNAscan-SE On-line: integrating search and context for analysis of transfer RNA genes. Nucleic Acids Research 44:W54-W57.

369

370

371

372

373

374

375

376

377
Mateos E, Tudó A, Álvarez-Presas M, and Riutort M. 2013. Planàries terrestres exòtiques a la Garrotxa. Annals de la Delegació de la Garrotxa de la Institució Catalana d'Història Natural 6:67-73.

Ogren RE, and Kawakatsu M. 1990. Index to the species of the family Geoplanidae (Turbellaria, Tricladida, Terricola): Part I: Geoplaninae. Bulletin of Fuji Women's College 28:79-166.

Ross E, Blair D, Guerrero-Hernández C, and Alvarado AS. 2016. Comparative and transcriptome analyses uncover key aspects of coding-and long noncoding RNAs in flatworm mitochondrial genomes. G3: Genes, Genomes, Genetics 6:1191-1200.

Sakai M, and Sakaizumi M. 2012. The complete mitochondrial genome of Dugesia japonica (Platyhelminthes; order Tricladida). Zoological science 29:672-680.

Solà E, Álvarez-Presas M, Frías-López C, Littlewood DTJ, Rozas J, and Riutort M. 2015. Evolutionary analysis of mitogenomes from parasitic and free-living flatworms. PLoS ONE 10:e120081.

Stamatakis A. 2014. RAxML version 8: a tool for phylogenetic analysis and post-analysis of large phylogenies. Bioinformatics 30:1312-1313. 


\section{Figure 1}

Amaga expatria, map of records in Martinique.

The background colours indicate annual raindrop falls. Most records are from the Northern part of the island where raindrops are high, but the record in Sainte-Luce in the South is a from a relatively drier part. Map by Jessica Thévenot, background provided by Météo-France and used with authorisation. 


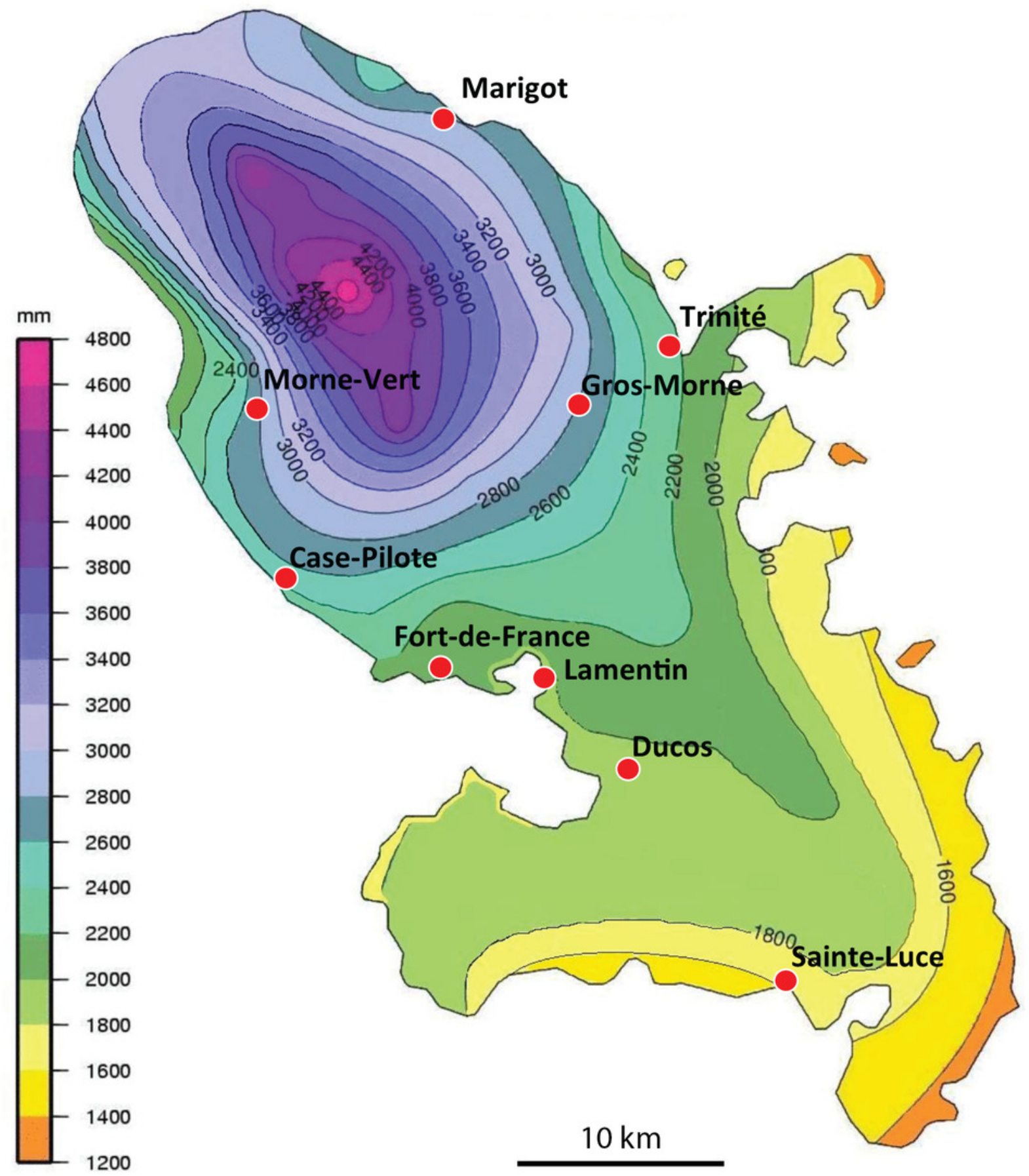


Figure 2

Amaga expatria, map of records in Guadeloupe.

The background colours indicate annual raindrop falls. Most records are from Basse Terre, where raindrops are high, but the record in Ste-Anne in Grande Terre is from a relatively drier part. Map by Jessica Thévenot, background provided by Météo-France and used with authorisation. 

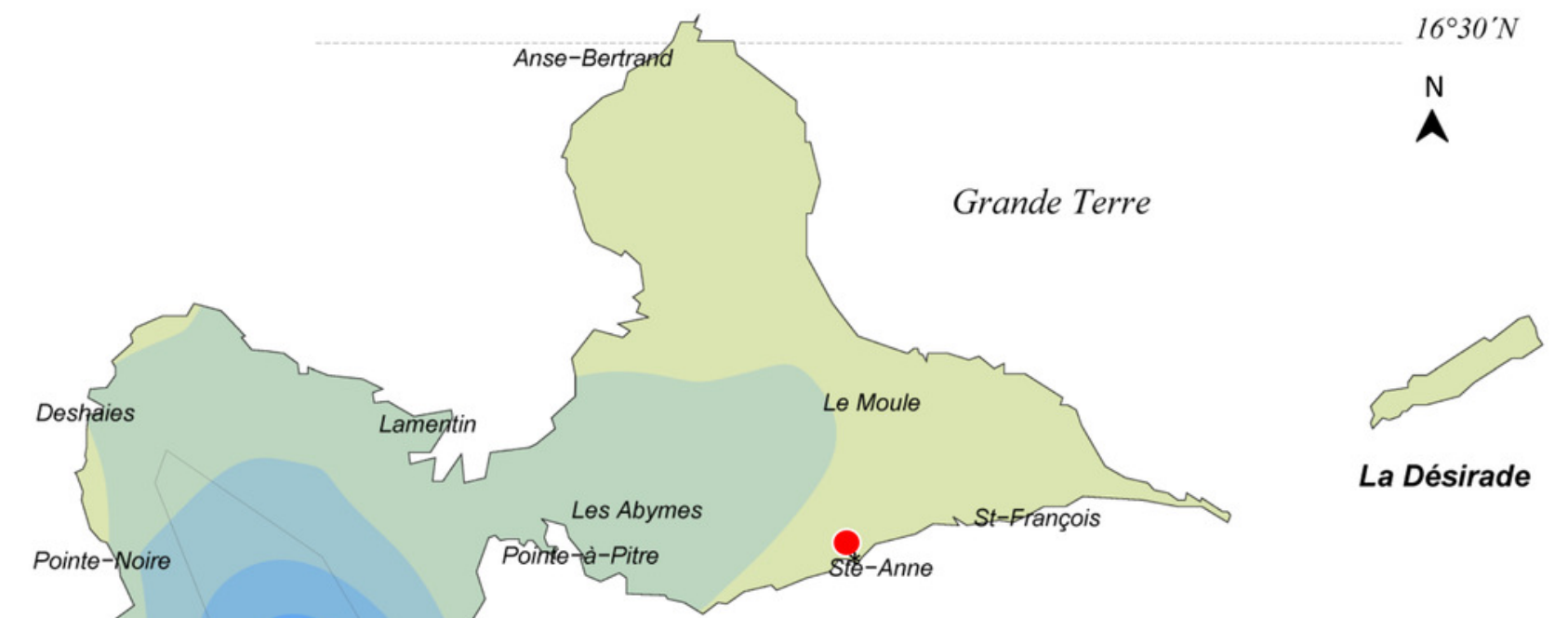

\section{Basse Terre}
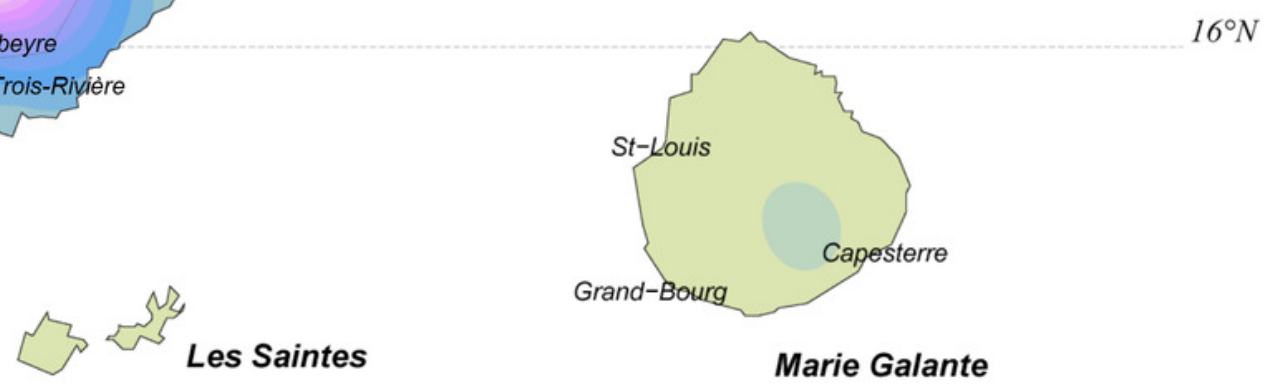

Marie Galante

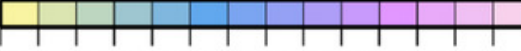

5001000150020002500300035004000450050005500600065007000 


\section{Figure 3}

Amaga expatria, specimen MNHN JL146 from Martinique

A, living specimen, photograph by Clément Dromer; scale: the diameter of the coin is $24 \mathrm{~mm}$; anterior tip is left. B, preserved specimen, photograph by Jean-Lou Justine. This specimen was used for anatomy.
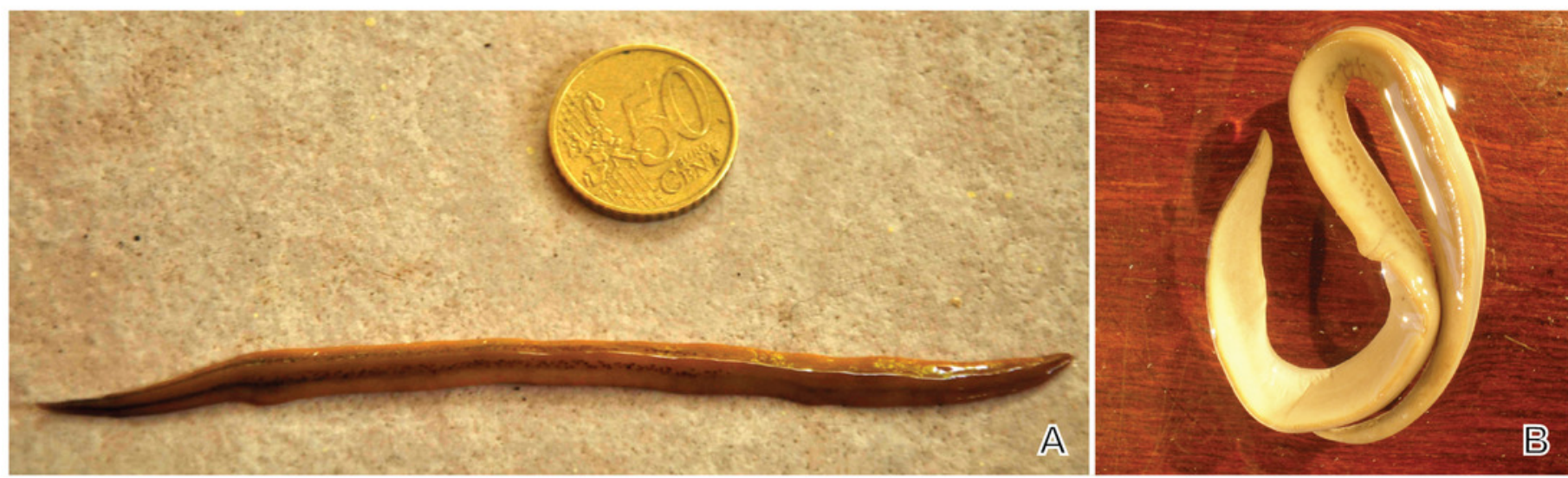
Figure 4

Amaga expatria from Martinique, living specimens.

A, photograph by Cedric Rareg; $B, C$ photograph by Régis Delannoye; C, scale in $\mathrm{mm}$; photograph by Mathieu Coulis, specimen MNHN JL305. Anterior tip is left for all specimens.

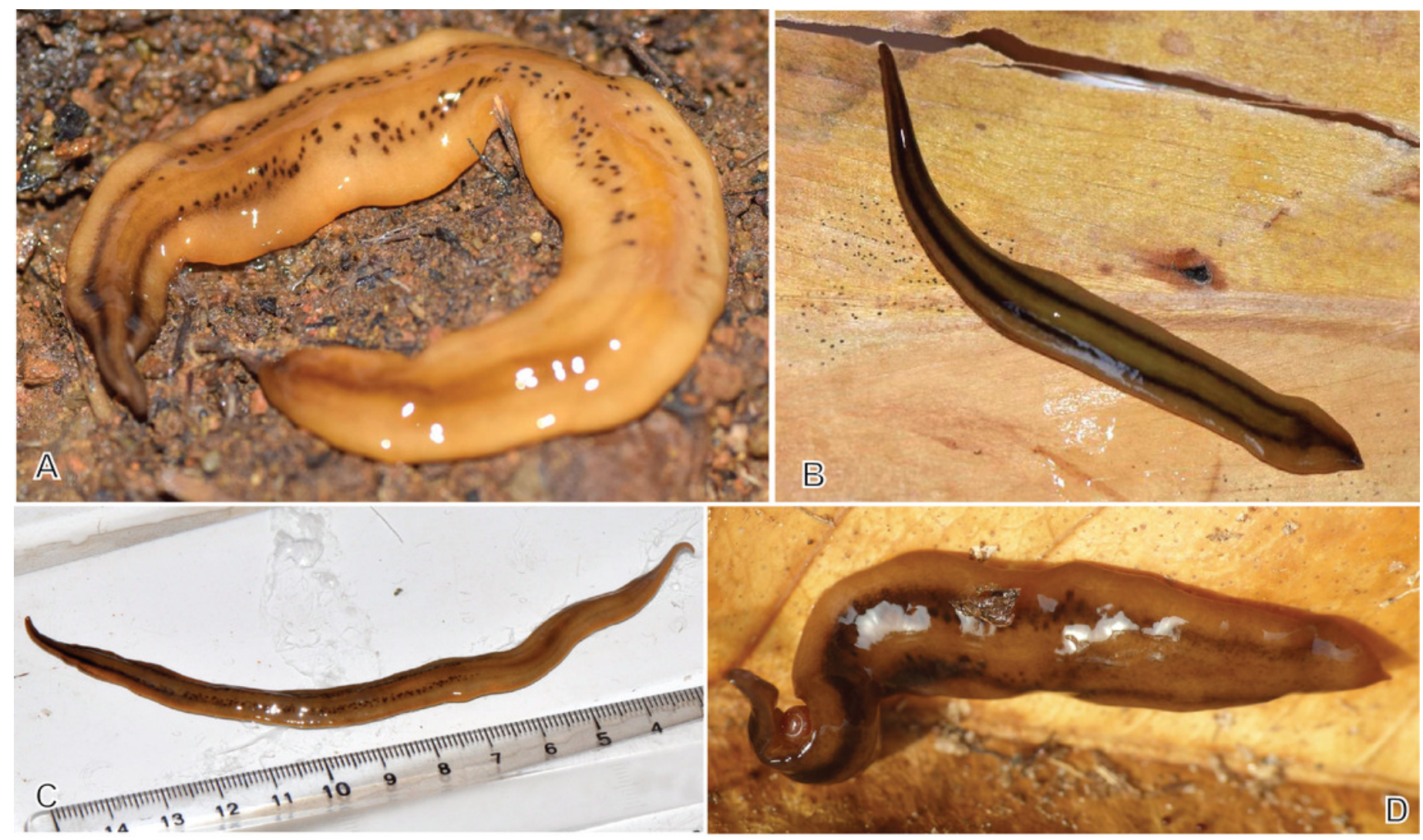




\section{Figure 5}

Amaga expatria from Guadeloupe, living specimens in the field.

A, photograph by Pierre and Claude Guezennec (anterior tip is left); B, C, photographs by Laurent Charles, B, specimen MNHN JL216, C, MNHN JL217; the prey snail is Helicina platychila; D, photograph by Mathieu Coulis, specimen MNHN JL310; E-G, photographs by Guy van Laere, E,F, specimen MNHN JL319, E, dorsal side, F, showing ventral side, G, specimen with damaged posterior part. 


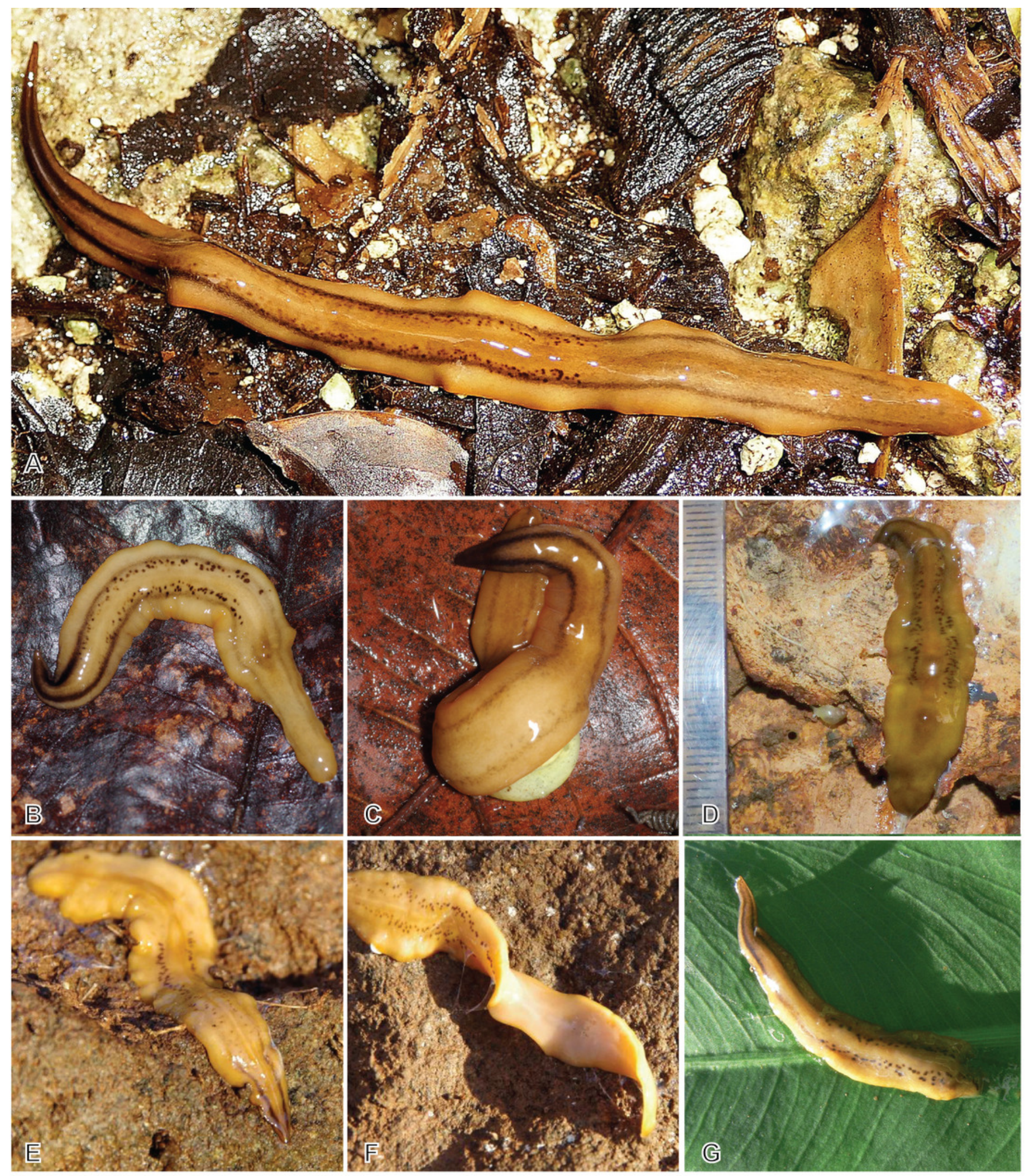




\section{Figure 6}

Amaga expatria, specimen MNHN JL146 from Martinique, anatomy.

Anatomy of the copulatory apparatus, anterior to the right: A, B, respectively an HLS section and a diagrammatic reconstruction through the copulatory apparatus to the same scale; $C$, posterior of the female ducts showing the junction of the ovovitelline ducts; D, anterior of the male ducts showing the junction of the sperm ducts, both with copious stored sperm (cyanophylic) with the ventral end of the vertical sperm duct. Abbreviations: ed, ejaculatory duct; jod, junction of the ovovitelline ducts; jsd, junction of the sperm ducts and the vertical sperm duct; od, ovovitelline duct; $p$, penis; sd, sperm duct; shg, shell gland; vsd, vertical sperm duct. Scales: A, B, $2 \mathrm{~mm} ; \mathrm{C}, \mathrm{D}, 500 \mu \mathrm{m}$. 


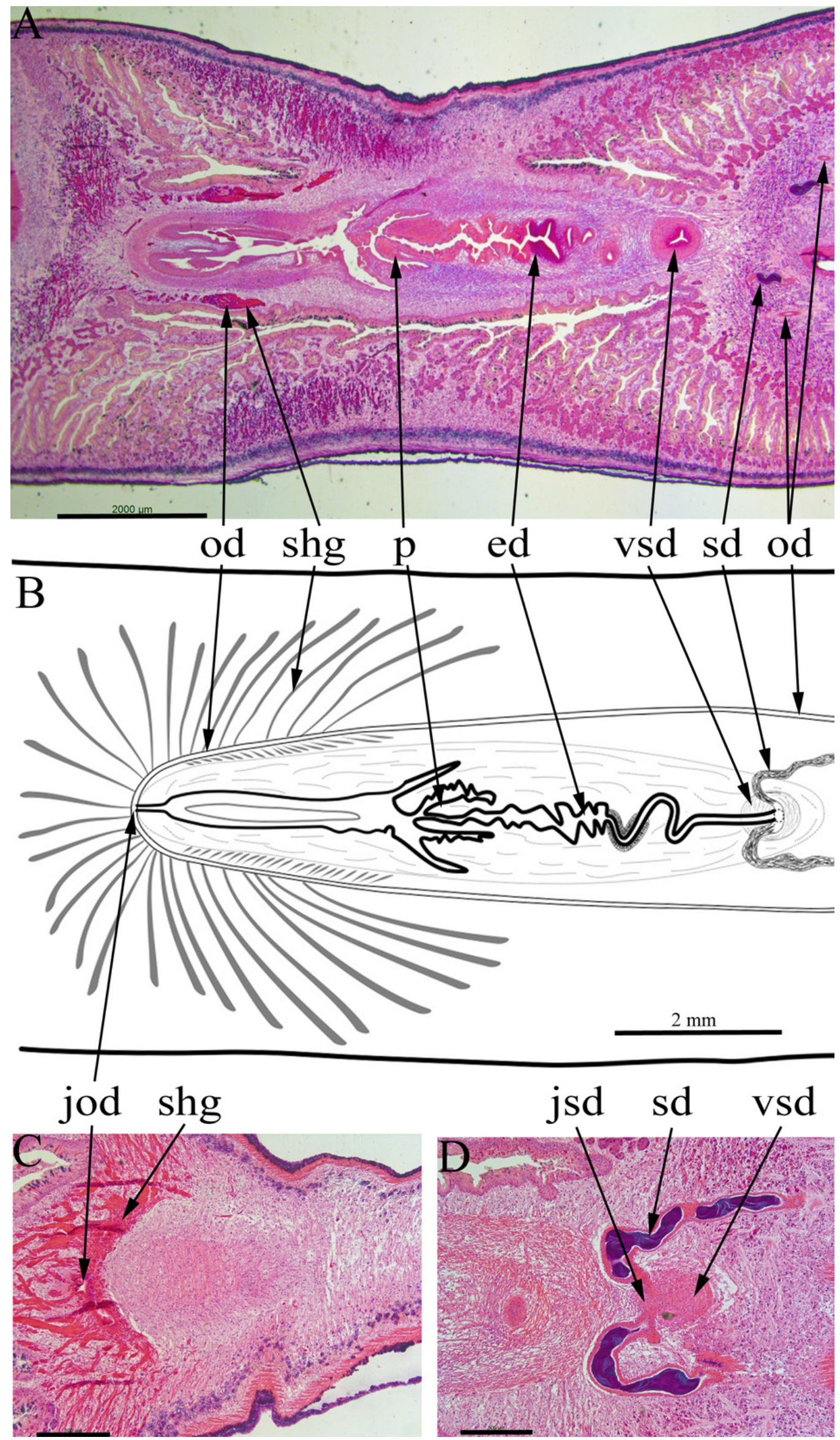

Peer] reviewing PDF | (2020:06:49873:2:0:NEW 8 Sep 2020) 
Figure 7

Amaga expatria, map of the mitochondrial genome.

The mitogenome is $14,962 \mathrm{bp}$ long and contains 12 protein coding genes, 2 ribosomal RNA genes and 22 transfer RNA genes. For 3 genes, atp6, cox2 and ND3, it was not possible to determine the start codon. 


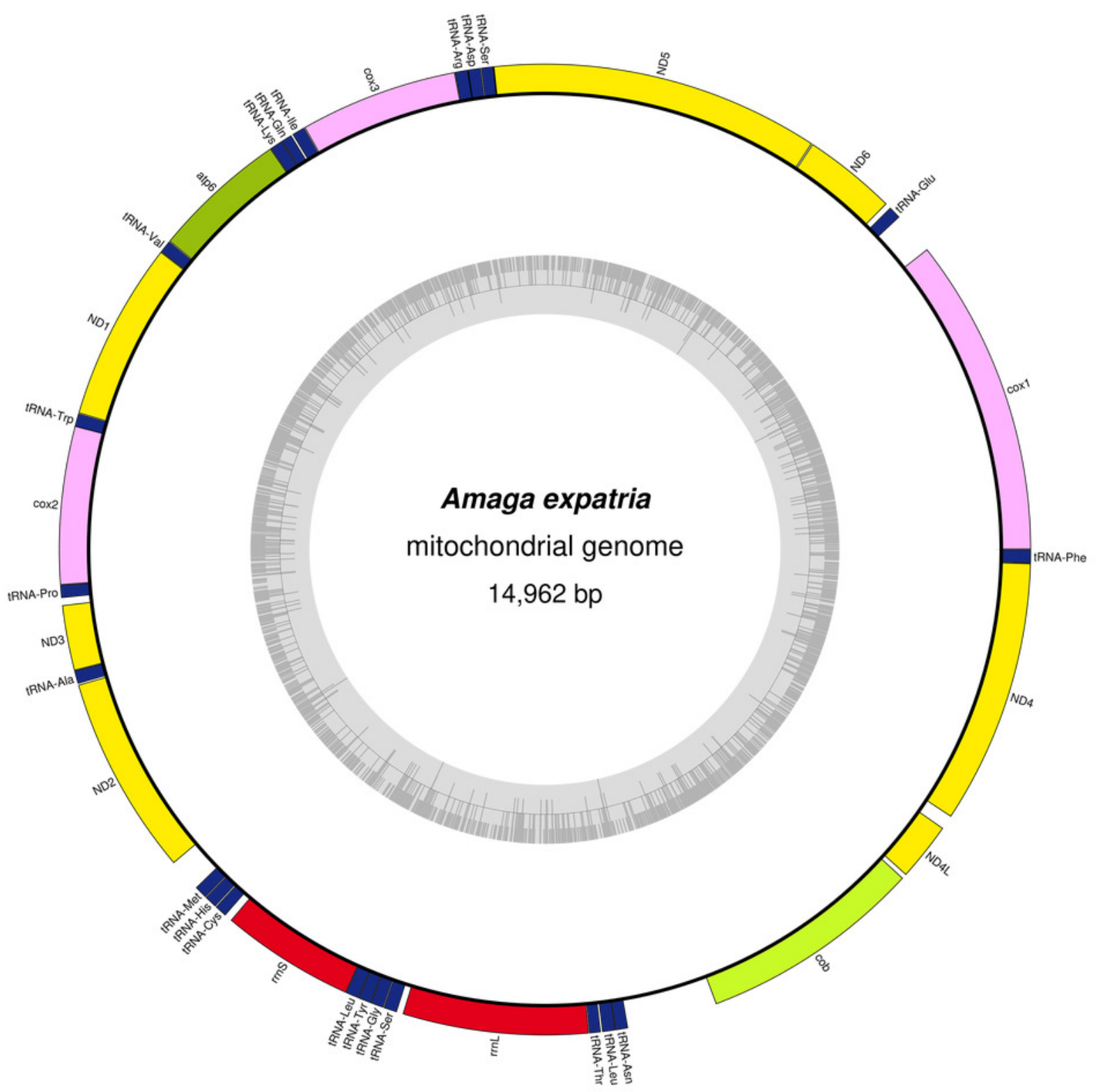

$\square$ complex I (NADH dehydrogenase)

complex III (ubichinol cytochrome $\mathrm{c}$ reductase)

complex IV (cytochrome c oxidase)

arponsene

transfer RNAs

$\square$ ribosomal RNAs 
Figure 8

Maximum likelihood tree of mitogenome proteins.

Mitogenome proteins were obtained from concatenated amino-acid sequences of all mitochondrial protein coding genes of Amaga expatria and other Platyhelminthes obtained using the MtArt model of evolution after 100 bootstrap replications. The tree with the best likelihood is shown (-62178.796969).

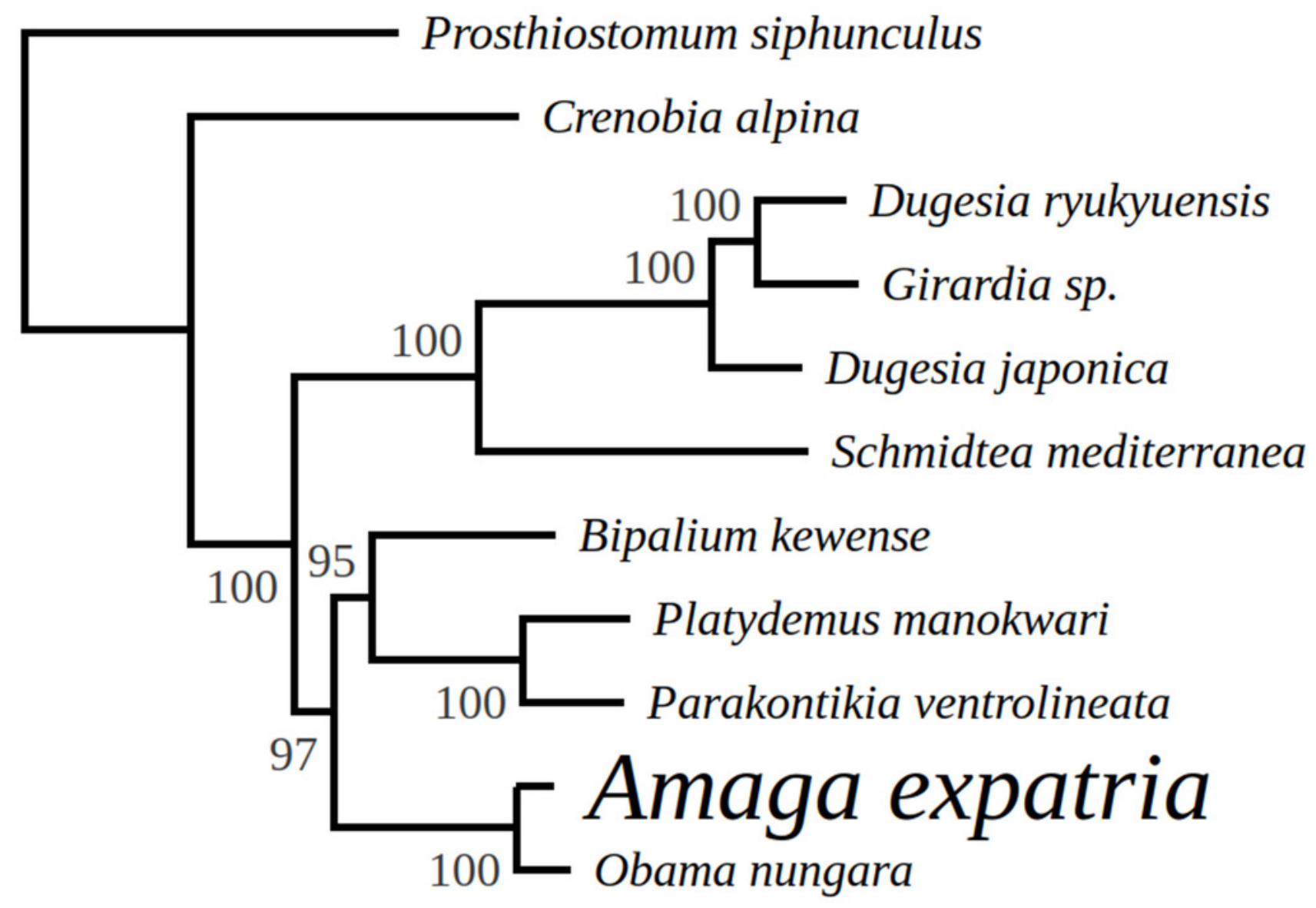

0.5 


\section{Table $\mathbf{1}$ (on next page)}

Records of Amaga expatria from Guadeloupe and Martinique.

The Table includes only observations based on photographs and specimens. François Meurgey provided additional findings in Guadeloupe: 10.10.2019, Goyave; 16.10.2019, Vieux-Fort; 22.06.2019, Petit Canal. * For MNHN JL305, we obtained both a COI sequence (GenBank MT602624) and the complete mitogenome (GenBank MT527191). 


\begin{tabular}{|c|c|c|c|c|c|c|}
\hline Date & $\begin{array}{l}\text { Record (specimen } \\
\text { number and } / \text { or } \\
\text { photo) }\end{array}$ & $\begin{array}{l}\text { Number } \\
\text { of } \\
\text { specimens } \\
\end{array}$ & Commune & Department & COI Sequences & Collector/Observer \\
\hline $28 / 02 / 2006$ & photo & 0 & Case-Pilote & Martinique & no & Régis Delannoye \\
\hline $17 / 08 / 2013$ & photo & 0 & Case-Pilote & Martinique & no & Régis Delannoye \\
\hline $25 / 11 / 2013$ & movie & 0 & Fort de France & Martinique & no & Anonymous \\
\hline $20 / 12 / 2013$ & photo & 0 & Le Lamentin & Martinique & no & Pierre Damien Lucas \\
\hline $06 / 05 / 2014$ & MNHN JL146 + photo & 1 & Le Gros Morne & Martinique & MT602619 & Clément Dromer \\
\hline $21 / 03 / 2015$ & photo & 0 & La Trinité & Martinique & no & Régis Delannoye \\
\hline $05 / 08 / 2015$ & MNHN JL262 & 1 & La Trinité & Martinique & MT602622 & Olivier Palcy \\
\hline $17 / 10 / 2015$ & photo & 0 & Le Gros Morne & Martinique & no & Pierre Damien Lucas \\
\hline $12 / 11 / 2015$ & MNHN JL305 & 1 & Le Morne Vert & Martinique & MT602624 * & Mathieu Coulis \\
\hline $13 / 11 / 2015$ & photo & 0 & Ducos & Martinique & no & Cedric Rareg \\
\hline $04 / 02 / 2016$ & MNHN JL289 & 1 & Le Marigot & Martinique & MT602623 & Régis Delannoye \\
\hline $18 / 06 / 2017$ & MNHN JL310 + photo & 1 & Le Lamentin & Martinique & MT602625 & Mathieu Coulis \\
\hline $22 / 06 / 2017$ & photo & 0 & Fort de France & Martinique & no & Marcel Bourgade \\
\hline $27 / 01 / 2018$ & photo & 0 & Sainte-Luce & Martinique & no & Stéphane Bras \\
\hline $12 / 02 / 2019$ & photo & 0 & La Trinité & Martinique & no & Régis Delannoye \\
\hline $20 / 12 / 2012$ & photo & 0 & Trois Rivières & Guadeloupe & no & Guy van Laere \\
\hline $06 / 12 / 2014$ & MNHN JL216 + photo & 1 & Gourbeyre & Guadeloupe & MT602620 & Laurent Charles \\
\hline $12 / 12 / 2014$ & MNHN JL217 + photo & 1 & Bouillante & Guadeloupe & MT602621 & Laurent Charles \\
\hline $21 / 01 / 2016$ & photo & 0 & Baillif & Guadeloupe & no & Pierre et Claudine Guezennec \\
\hline $20 / 12 / 2017$ & MNHN JL319 + photo & 1 & Trois Rivières & Guadeloupe & MT602626 & Guy van Laere \\
\hline $06 / 08 / 2018$ & photo & 0 & Sainte-Anne & Guadeloupe & no & Jean-Christian Rotger \\
\hline
\end{tabular}

